\title{
ICT Opportunities and Threats in Implementing Teaching Practice Programmes
}

\author{
Benkosi Madlela \\ Department of Education, Faculty of Science and Technology, University of South Africa (UNISA), South Africa
}

Copyright (C) 2015 by authors, all rights reserved. Authors agree that this article remains permanently open access under the terms of the Creative Commons Attribution License 4.0 International License.

\begin{abstract}
Mthwakazi University (MU) established the teacher education department in 2005. The purpose of this department is to empower teachers especially those who did not do education in their first degrees with pedagogical skills and competencies that will make them effective teachers in the classrooms. Students in this teacher education

utilised in the implementation of teaching practice programmes. The study concluded that ICT opportunities do exist, and these opportunities can be exploited in order to improve the implementation of TP programmes. Threats also exist but these threats can be turned into opportunities if a proper ICT Policy is enacted at MU.
\end{abstract} department come from all the five Provinces of Mthwakazi, Bulawayo, Matabeleland South, Nkabazwe, Matabeleland North, and Mpumalanga. After learning for a year during their second year they are sent for teaching practice in schools located in different geographic Provinces of the country. In the quest of bridging the gaps created by time and distance MU department of teacher education is in the process of integrating ICT into their teaching practice programmes for the purposes of conveniently reaching out to their students who are partaking in teaching practice in schools. The department is of the opinion that ICT would enhance the effectiveness and efficiency in running teaching practice programmes. The study investigated how MU department of teacher education is exploiting ICT opportunities in the implementation of its teaching practice programmes, and the kind of infrastructure that is available to support such integration, the challenges encountered as well as opportunities available in the implementation process. Literature was reviewed in order to gain a wider picture of ICT integration in teaching practice programmes. Literature review came handy in giving an overview of what ICT integration in teaching practice programmes entails. It also highlighted the opportunities and challenges associated with it, as well as possible solutions to the challenges. The study used interviews as an instrument of collecting data form lecturers and students in the department of teacher education at MU. After literature review, qualitative data presentation and analysis, recommendations were made as to how best ICT opportunities can be utilised in implementing teaching practice programmes at MU, and how challenges faced during implementation can be solved or turned into opportunities. The findings of the study were shared with MU's department of teacher education and other teachers' training colleges during cluster group workshops and meetings. Such knowledge sharing will help teachers' training institutions to find ways on how best ICT can be
Keywords ICT, Opportunities and Threats, and Implementing Teaching Practice Programmes

\section{Introduction} Technology (ICT) changed the teaching practice landscape in the $21^{\text {st }}$ Century. Research findings and literature review from authorities such as Clarke (1), Harris \& Anthony (2) and Oliver (3) proved that ICT provides both opportunities and challenges in the implementation of teaching practice (TP) programmes. The case study of Mthwakazi University (MU) demonstrates that ICT presents opportunities that can be utilised in teaching practice programmes in order to improve such programmes. It also emerged from respondents and authorities such as Oliver (3) that despite having vast opportunities ICT has threats and challenges as well in the implementation of teaching practice programmes. These threats and challenges need to be remedied or turned into opportunities in order to ensure successful integration of ICT in the implementation of teaching practice programmes. The study took teaching practice programmes among others as involving supervision, supporting, coaching and mentoring of student teachers by their lecturers, senior teachers, and local mentors while on teaching practice.

Aim of the study

The aim of the study was to investigate the types of ICT opportunities that could be utilised by MU in the implementation of its TP programmes, and the kind of threats that could inhibit such an implementation.

Research Questions
The advent of Information and Communication 
The study intended to answer the following question:

- Which ICT Opportunities could be exploited by MU in the implementation of its teaching practice programmes?

- What kind of threats could inhibit the use of ICT in the implementation of teaching practice programmes at MU?

\section{Research Methods}

Since this was a qualitative study data was collected using face to face interviews because they generate comprehensive information. Rogers (4) argues that face to face interviews are ideal for collecting data, because they allow the researcher to probe, and clarify questions in order to get accurate and sufficient information from respondents. Interviews proved to be more convenient than the initial intended focus group discussions because student teachers were far apart in their schools while lecturers were always busy in their offices, so there was no time for grouping them into focus groups. Face to face interviews proved to be ideal in this prevailing situation.

\section{Population}

Population according to Welman (5) is a group of people where participants for the study are selected from. Mthwakazi University lecturers and student teachers doing teaching practice in the field in schools constituted the population for the study.

\section{Sampling}

Rogers (4) defines sampling as a way of choosing participants who will participate in the study. Random sampling was used. Three lecturers from MU and three student teachers on TP were randomly selected to participate in the study. McMillan and Schumacher (6) contend that in random sampling each member of the population or of a sub-group has an equal probability of being selected. Random sampling also made it possible to generalise findings of the study to the whole population of $\mathrm{MU}$ Department of teacher education lecturers and student teachers on TP.

\section{Information and Communication Technology (ICT)}

Thomas (7) asserts that Information and Communication Technology (ICT) is often used as an extended synonym for information technology (IT), but is a more specific term that stresses the role of unified communications and the integration of telecommunications, telephone lines, and wireless signals, computer as well as necessary enterprise software, middleware, storage, and audio-visual systems, which enable users to access, store, transmit, and manipulate information. On the other hand Oliver (3) argues that, the term ICT is now also used to refer to the convergence of audio-visual and telephone networks with computer networks through a single cabling or link system.

ICT refers to technologies that provide access to information through telecommunications. It is similar to Information Technology (IT), but focuses primarily on communication technologies. This includes the internet, wireless networks, cell phones and other communication mediums. In the past few decades information and communication technologies have provided society with a vast array of new communication capabilities, for example people can communicate with others in different places using technologies such as instant messaging, voice over IP (VoIP), and video conferencing. Social networking websites like Facebook, twitter, allow users from different Geographical places to remain in contact and communicate on a regular basis. Modern information and communication technologies have created a global village in which people can communicate with others in different places and across the world as if they were living next door www.techterms.co/definitions.ict accessed on the 10th of June 2014. In line with this Toomey (2001) cited in Margaret (8) argues that ICT generally relates to those technologies that are used for accessing, gathering, manipulating and presenting or communicating information. These technologies could include computer hardware and software, and other applications and connectivity for example access to the internet, local networking infrastructure and video conferencing. Toomey (2001) cited in Margaret (8) continues to argue that, what is most significant about ICT is the increasing convergence of computer based multimedia and communications technologies and the rapid rate of change that characterises both the technology and their use.

\section{Teaching Practice}

School for Initial Teacher Education, source site.nmmu.ac.za/Teaching-Practice, accessed on the $16^{\text {th }}$ of June 2014 attests that, teaching practice experience provides opportunities for student teachers to integrate theory and practice, and work collaboratively with and learn from experienced teachers. Student teachers observe qualified and experienced teachers teaching in class so that they learn about teachers' skills, attitudes, strategies and classroom achievements. They also evaluate their own teaching through conferencing with experienced teachers, lecturers and through self-reflection. This helps them to implement a variety of approaches, strategies and skills with a view to bring about meaningful teaching and learning. Through observing senior teachers student teachers gain experience in managing and evaluating class work, maintaining discipline and good order in the classroom, finding their own teaching style and personality, as well as becoming acquainted with school organisation and administration. Marais \& Meir (2004:221) cited in Kiggundu \& Nayimuli (9)on the other hand contend that the term teaching practice represents the range of experiences to which student teachers are exposed to when they work in the classroom and schools. Lave \& 
Wenger (10) argue that teaching practice is entrenched in experience based learning initiated by Dewey (1938), Vygotsky's (1978) social cognitive theory, and founded in the premise of situated learning. Kiggundu \& Nayimuli (9) attest that the South African norms and standards for educators, Republic of South Africa (2000:12) suggests that, teaching practice is meant to provide for the authentic context within which student teachers are exposed to experience the complexities and richness of the reality of being a teacher. Based on the assertions of authorities it can be said that teaching practice is a programme that initiates a student teacher into the teaching profession.

\section{ICT opportunities in implementing TP Programmes}

In order to implement TP programmes successfully and effectively relevant ICT opportunities should be exploited. As earlier highlighted TP programmes involve supervising, evaluating, supporting, coaching and mentoring student teachers during their teaching practice exercise. Other TP programmes pertain to assessing how student teachers deliver lessons in class, evaluate student learning, assess students' work and give them feedback. All this can be done better by lecturers, local mentors and student teachers if relevant ICT opportunities are identified and appropriately exploited. Supervising student teachers on TP is usually a challenge due to distance, time and resource constraints. In order to overcome these constraints such supervision can be done using effective and relevant ICT apparatus.

Using ICT to supervise student teachers on TP

The integration of ICT into TP programmes is recognised by Clarke (1) as providing opportunities for the successful implementation of TP programmes in the $21^{\text {st }}$ century. Clarke (1) sees ICT as having the potential of transforming and modernising ways and techniques of implementing TP programmes.

Interactive Education Multimedia, number 14 (April 2007) asserts that ICT enables virtual communication between university supervisors and student teachers in the field doing their TP. On the other hand Hammond (11) argues that student teachers in their first days in the field face problems such as, negative attitudes of learners regarding tasks proposed, learners' misbehaviour, lack of support from colleagues, inadequate planning for classes, and administrative bureaucracy. These problems according to Hammond (11) can be dealt with through getting support from the supervisor or the mentor. Supervisors are usually in university campus far away from student teachers. ICT closes the gap created by distance, and necessary support can come from supervisors and mentors through the use of e-mails, and cell phone messages. Harris \& Anthony (2) are of the opinions that, student teachers can get support that they need to solve problems that they encounter through social networks such as Whatsapp, twitter and Facebook with colleagues, mentors and supervisors. This way ICT is seen as a tool that affords student teachers an opportunity to be supported by their colleagues, mentors and supervisors regardless of the distance involved and time constraints.

Interactive Education Multimedia, number 14 (April 2007) goes on to say that, through ICT virtual supervision of student teachers by their lecturers is possible. For example student teachers can e-mail their lecturers/supervisors schemes of work, lesson plans, profile of learners, criteria of assessing and evaluating learners, discussion of classroom episodes and the like. On receipt of these the supervisor acts accordingly and gives appropriate feedback. Student teachers can also e-mail their supervisors when they have questions or minor problems that need the supervisor's attention. At times students can e-mail or send SMSs to make appointments with their supervisors.

Clarke (1) attests that ICT advancement in the 21st century gives student teachers and supervisors an opportunity to audio-conference or video conference about certain issues that need attention. She contends that it also gives student teachers an opportunity to embark on on-line discussion forums with colleagues, and at times with their supervisors for the purposes of discussing teaching practice challenges, procedures, and successes.

\section{Challenges of using ICT to supervise student teachers on TP}

Though ICT offers vast opportunities in supervising student teachers partaking in their TP, but it also has some challenges that are worth mentioning. Cluckle, Clarke, \& Jenkins (1) accentuate that, some student teachers doing TP in remote areas do not have access to computers, while some lack ICT resource support from the administration of their schools. Such resources include ICT hardware and software. This assertion is supported by Thomas (7) who argues that, the majority of schools where student teachers are deployed to do their TP lack ICT infrastructure that can support the use of ICT supervision by college and university lecturers.

Oliver (3) attests that some teacher training colleges and universities do not invest in ICT at all. Its either they don't have ICT infrastructure or they have an out-dated one that can not sufficiently support the implementation of TP programmes. He goes on to say that such teacher training institutions do not even embed ICT into their teacher training curriculum and TP programmes, as a result both lecturers and student teachers do not develop the culture of using ICT in their pedagogical activities and programmes. This assertion is in line with Hammond (11) who argues that student teachers themselves resist the use of ICT, because they lack ICT culture and expertise due to the fact that the majority of them are not even introduced to ICT basics in their teacher training colleges and universities.

Cluckle etal (1) argues that most students doing TP in the country side have no access to the internet, cell phone network and electricity. He there-fore sees lack of these vital resources not only as inhibiting factors, but as a serious threat to the endeavours of using ICT to supervise students on teaching practice.

\section{Research Findings}

Three MU lecturers involved in TP programmes and 3 
student teachers doing their TP partook in the study. Face to face interviews with students and lecturers were used to collect data. The study intended to answer the following question:

- Which ICT Opportunities could be exploited by MU in the implementation of its teaching practice programmes?

- What kind of threats could inhibit the use of ICT in the implementation of teaching practice programmes at MU?

From data presentations and analysis the following headings emerged:

\section{An overview of ICT in education}

Lecturers 1 said that, ICT is an acronym for Information and communication technology. She went on to say that ICT must be viewed on a broader perspective as a tool that can be used to deliver lessons in class, supervise and mentor student teachers on TP. According to her computer connected to the internet can be used to conduct scientific simulations and to generate scientific data. Students 1 who was on TP, said that ICT encompasses using technology to deliver lessons, and to facilitate communication between student teachers and their supervisors. This assertion is supported by Newhouse (13) who argues that computers should be brought into the teaching practice field in order to improve communication between student teachers and their college supervisors.

\section{ICT infrastructure at MU}

The study revealed that MU does not have ICT infrastructure designated for TP programmes. The infrastructure that is available is as follows:

- Telephone (land line).

- Personal cell phones of lecturers.

- Computer lab with internet connectivity that is used by all students in the university but has no connection with TP programmes.

- University face book page where the university communicates with all its students.

- 1 laptop that is used by the head of TP programmes, but it is not connected to the internet.

- Old desk tops that are not connected to the internet in supervisors' offices

- Khalid (14) sees lack of proper ICT infrastructure in developing countries as one of the major barriers that inhibit the use of technology in the implementation of education programmes such as lesson delivery and teaching practice programmes.

Teaching practice programmes at MU

MU's department of teacher education lecturer 2 and 3 concurred on the fact that MU department of teacher education has 3 TP programmes with a variety of activities under them. These are:

- Bachelor of Education Primary pre-service (BED)

- Bachelor of Education Secondary pre-service(BED)

- Post Graduate certificate in education (PGCE)
Details of these programmes are illustrated below in the table.

\begin{tabular}{|c|c|c|}
\hline Programme & $\begin{array}{c}\text { Duration of the } \\
\text { programme }\end{array}$ & $\begin{array}{c}\text { Duration of teaching } \\
\text { practice }\end{array}$ \\
\hline BED Primary & 3 years & $\begin{array}{c}5 \text { weeks in year 2, 5 weeks } \\
\text { in year 3. A total of } 10 \\
\text { weeks }\end{array}$ \\
\hline BED Secondary & 3 years & $\begin{array}{c}5 \text { weeks in year 2, 5 weeks } \\
\text { in year 3. A total of } 10 \\
\text { weeks }\end{array}$ \\
\hline PGDE & 1 year & 10 weeks done at once \\
\hline
\end{tabular}

Lecturer 3 said that when they are supervising student teachers on teaching practice they use the assessment form that contains the following sections:

1. Documentation- under this section she said they look on the schemes of work and lesson plans. They check whether these documents are up to date, the format is up to stipulated standards; lesson objectives are SMART and clearly articulated.

2. Classroom management and professional conductunder this section lecturer 3 said they check whether the teacher's dress code and behaviour are in line with the Public Service Commission's (PSC) code of conduct. For example MU expects male teachers to put on formal trousers, shirts, shoes as well as a neck tie. Female teachers are expected to put on formal dresses and skirts. Lecturer 3 went on to say that they also observe the teacher's skills and competencies of controlling the behaviour of learners in class during lessons.

3. Lesson delivery - lecturer 1,2 and 3 all agreed that under this section they check the following:

- How the teacher introduces the lesson.

- Lesson development including teaching methods used.

- Linkage between subject content delivered and the lesson objectives stated in the lesson plan.

- The teacher's content knowledge i.e. his/her knowledge of the subject being taught.

- Scope and pace of the lesson.

- Resource use and their appropriateness.

- Learner involvement in terms of their contributions, as well as the teacher's use of their experiences and their everyday life activities.

- Types of questions asked i.e. are they high order or low order or both.

- Confidence of the teacher.

1. Assessment- this according to lecturer 2 includes tests, classwork and assignments that have been administered and those that are yet to be administered including marking schemes that are used to mark learners' work. The existence and standards of marklists is also checked.

2. Evaluation- under this section lecture 1 and 3 said they check how teachers evaluate their lessons. Is their evaluation comprehensive? Does it if necessary suggest what needs to be done in order to remedy certain 
situations experienced during lesson delivery? The marking scheme is also analysed in order to find out whether it clearly shows how marking will be done as well as how marks will be allocated.

3. Core-curricular activities- This according to lecturer 2 include activities such as music, drama, sports and the like. He said they also check the kind of core-curricula activities that student teachers participate in during their teaching practice.

\section{ICT opportunities in Teaching Practice (TP)}

All lecturers 1, 2 and 3, agreed that ICT if well introduced and managed in the implementation of teaching practice programmes it is capable of bringing a lot of opportunities and benefits to MU. Lecturer 3 said that currently they are supposed to see each student on TP 5 times but due to time and distance constraints they end up seeing certain students 2-3 times. This is mostly pronounced on students who are deployed in the periphery of the country. She there-fore argues that if up to date ICT is used to assess students on teaching practice the frequency of student assessment can increase, because ICT can enable the supervisor to assess through a web camera 5 or more students per day in the comfort of his/her office as opposed to assessing 1 or 2 students per day as the case is in faraway rural schools that are tens and tens of kilometres away from each other where the only access is through unmaintained or poorly maintained dust roads. This is in line with Reddi (15) who contends that when using ICT distance does not matter, because recipients such as students could be accessed anywhere and given a speedy and uniform quality service as long as they are connected. This means that through the use of ICT long distances and poor roads are not an issue because lecturers could still assess their student teachers in the comfort of their offices using technology. Lecturer 3 was of the opinion that if the frequency of assessing student teachers on TP increases, automatically the quality of outputs would improve, because the use of ICT would make it possible to supervise students as many times as necessary. The first round of assessment could be used to give support to students. The second round used to check progress and to give feedback. Then other coming rounds could then be used for assessment and marks.

Lecturer 1 was of the opinion that proper ICT infrastructure could enhance the efficiency of supervision of student teachers on TP. She believed that up to date ICT infrastructure would make it possible to upload for students access the TP modules and guidelines. She went on to say that through ICT the following activities could be done on line:

- Student teachers could consult their supervisors on line if need arises.

- Documentation could be sent by student teachers to their supervisors online and be assessed on line and feedback be instantly given online by supervisors. These documents according to her include among others schemes of work, lesson plans, marklists, marking schemes, and power point slides.

- Online coaching and mentoring of student teachers by supervisors and local mentors.

- Online discussions and sharing of ideas by student teachers through face book groups.

- Posting and sharing of information about teaching practice through whatsapp groups formed by student teachers.

Lecturer one's assertion is similar to Harris \& Anthony's (2) opinions that, student teachers can get support that they need to solve problems that they encounter during teaching practice through social networks such as Whatsapp, twitter and Facebook with colleagues, mentors and supervisors.

Responding to the costs concerns of installing and running ICT infrastructure lecture 2 said that in a long run ICT makes the implementation of TP programmes much cheaper because it reduces distance and time needed to administer TP programmes. He said that currently the cost of running TP programmes is very high because many schools are located far away from the university and they are far apart from each other. Due to distance involved he said that they end up spending a lot of money on transport, and accommodation of supervisors. He went on to say that during TP period all supervisors are always away from their offices to the detriment of on-going programmes and activities in the university. In light of this he believed that when TP is to a larger extent implemented through the use of ICT less time would be needed for supervisors to administer TP programmes, because they would do a lot of these activities in the comfort of their offices without moving longer distances for several days. This therefore according to him would reduce the disruption of other university activities and programmes during TP period. Reddi (15) and Khalid (14) argue that the use of ICT in the implementation of teaching programmes mitigates against factors such as distance and costs associated with the running of such programmes. Lecturer 1 also said that if TP programmes are implemented using ICT a much needed culture of using ICT to deliver lessons in class would be cultivated and sustained amongst lecturers and student teachers. This assertion by lecturer 1 of introducing ICT to administer TP programmes is supported by Newhouse (13) who argues that teachers are not given an opportunity to learn technology, and this opportunity can be availed to them through introducing technology to run TP programmes in order to inculcate in teachers the culture of using technology.

Student 1, 2 and 3 who were doing their TP in different schools and provinces said that proper ICT infrastructure would enable them to constantly get help from their supervisors without necessarily having to make appointments and travelling for many kilometres to the university. This assertion is supported by Reddi (15) who attests that in the implementation of education programmes ICT reduces barriers such as distance and any other factors such as bad weather and time. Student 2 asserted that through ICT they could easily get the much needed support from their 
supervisors, mentors and colleagues. She went on to say that through the use of e-mails, cell phones, and social media networks such as face book, twitter, whatsapp, mixit etc, student teachers could get customised help from their supervisors, local mentors and colleagues. She saw that as of utmost importance as it was likely to boost the student's confidence and performance during teaching practice. According to her if they wanted to make appointments with their lecturers as students they simply e-mailed or sent SMSs to their lecturers who in turn gave instant feedback. Student 3 highlighted that through e-mails, SMSs, whatsapp and face book they are able to ask their lecturers questions, and lecturers are able to give them quick feedback through these mediums. In line with this lecturer 1 highlighted that the university's face book page enables them to make important announcements to students on TP. She went on to assert that through ICT their students on TP do not need to travel long distances to submit their assignments at the university but they can do the submission on line in their respective schools or in near-by areas offering internet services. The third year Bachelor of Education (BED) students doing teaching practice are also enabled to e-mail their project proposals and chapters to their lecturers without necessarily having to travel for longer distances to the university. On receipt of these proposals and chapters lecturers e-mail back feedback to students so that they could adapt accordingly. This system makes the handling of assignments and supervision of projects of students on TP convenient and effective.

\section{ICT threats in implementing TP programmes}

Lecturer 2 said that the opportunities of using ICT to implement TP programmes are inhibited and threatened by lack of adequate and up to date ICT infrastructure at MU. For example he contended that the number of computers in the university was not enough, and there were no computers that were designated for TP, while other computers were not connected to the internet. This had resulted according to him in other lecturers resorting to supervising student teachers through phone calls and e-mails only. Lecturer 1 said that she didn't want to supervise students through the telephone, because she wanted to see the lesson practically, how the teacher conducts it, how learners respond, how he/she distributes questions in class, how deviant students are being managed in class. She believed that all this could be possible if a web camera is used. She continued to say that using e-mails was also not adequate because it doesn't enable the supervisor to see physically what transpires in the classroom during lesson delivery.

Lecturer 2 went ahead to say that apart from having inadequate computers for students, some lecturers also did not have computers, and some of those who had were not connected to the internet. Lecturer 1 was worried by the fact that many lecturers were too traditional; they were not comfortable to use ICT even when delivering lessons in class. The situation there-fore gets worse when it comes to using ICT to implement TP programmes. She said that some students as well did not have ICT skills and knowledge. Some didn't even have e-mail addresses. These assertions are supported by Pelgrum (17) cited in Khalid (14) who argues that barriers and challenges of ICT integration into education programmes pertain to insufficient number of computers or copies of software, as well as teachers' insufficiency in ICT knowledge and skills. Lecturer 1 criticised the university curriculum that had not yet incorporated ICT into teacher training programmes. She was of the opinion that if the university is serious in using ICT to implement TP programmes the beginning point must be introducing ICT in the teacher training programmes. On the other hand lecturer 3 highlighted that the main challenge to using ICT to implement TP programmes was that from the time the university embarked on this programme no specialists or consultancy has been engaged to set up the programme and relevant infrastructure with customised modern and up to date hardware and software. She said that this has not yet been done because the university has not yet been serious to commit a realistic budget for the project of setting up ICT infrastructure for TP programmes. She went on to express her concern that as long as there was no commitment from the university management to come up with the budget to set ICT infrastructure that would support TP programmes, then the whole project would fail to take off.

On the other hand lecturer 1 added that the major threats that she perceived pertained to the fact that the life span of ICT infrastructure is too short. The ICT hardware and software need to be replenished now and then. This according to her further aggravates costs associated with the setting up and running of such infrastructure. Her concerns also pertained to ICT infrastructure security. She thought that safeguarding hardware and information in computers is problematic especially during these days of cyber war. She also believed that students and any other hackers could crack into the system and alter, temper with or distort data; she also argued that it was possible for viruses to erode TP information in computers. Shelly, Gunter \& Gunter (16) see viruses and crackers as posing major threats to information stored in education institutions' computers.

Student 2 and 3 concurred that the major threats to using ICT to implement TP programmes at MU were that, many schools especially those in rural areas have no ICT culture. In the majority of these schools according to student 2 both the school management and teachers are computer illiterate. They don't even know what a computer mouse is. Most schools do not have computers, even those that have, have unmaintained old versions that are not even connected to the internet. She contended that in most rural areas where many schools are located there is no internet, cell phone network, and electricity. This according to her makes it difficult for student teachers to use ICT to communicate with their lecturers, mentors and colleagues about teaching practice issues. This assertion is in line with Khalid's (14) argument that most teachers lack ICT skills and knowledge, and 
Newhouse's (13) research that found out that, many teachers lacked the knowledge and skills to use computers and were not enthusiastic about the changes and integration of supplementary learning associated with bringing computers into their teaching practices. This according to him is mostly pronounced in developing countries. Lecturer 1 said that the major concern about using ICT to implement TP programmes at MU pertained to the fact that many schools if not all of them are not connected to the university network. Lecturer 1 asserted that if the project was to work the university needed to be connected through intranet with all the schools where students do their TP. She argued that if that was not done it would be difficult for the University and student teachers to linkup and to share information.

During the interviews participants suggested some solutions to the threats that they raised. Lecturer 3 suggested that the majority of threats in using ICT to implement TP programmes at MU could be reduced if a proper and adequate budget is put in place to hire competent consultancy to set up, manage and maintain ICT infrastructure capable of supporting TP programmes. Lecturer 2 asserted that the threat of lack of support of the project by traditional lecturers could be eliminated through training all lecturers in ICT especially on how to use it to implement TP programmes and to deliver lessons in class. He suggested the same for student teachers. He thought that introducing ICT into the curriculum will motivate students to use the system when they are on teaching practice to communicate with their supervisors, mentors, colleagues and their learners. The finding of Pelgrum's (17) study was that there were not enough training opportunities for teachers in the use of ICT. In light of this he suggested that teachers should be trained on how to successfully integrate ICT into education programmes

Lecturer 3 suggested that the threat of theft of computers could be dealt with through boosting up both physical and surveillance security, while hacking and viral corruption could be dealt with through using up to date firewalls and anti-viral software. Her suggestions go hand in hand with Shelly, Gunter \& Gunter (16) who argue that, ICT infrastructure and information in schools could be safe guarded through employing effective security systems such as surveillance cameras, access control system, antivirus software as well as installation of firewalls.

All Students 1, 2 and 3 were of the opinion that students could benefit from the project if ICT could be taught in the university's teacher training curriculum. Khalid (14) is of the same opinion that in order to exploit the potential of ICT fully resulting in improved students outcomes there is need for educators to incorporate those new technologies into teacher training programmes. Pertaining to lack of computers, electricity and internet in rural areas where their schools are located, students said that such challenges could be solved if schools through the Department of education work with the Ministry of water and energy supply's department of rural electrification to try and accelerate the pace of rural electrification, and to prioritise schools in its programme. To them electrification project would attract the internet connection which would make it possible for rural schools to be connected. They also suggested that the issue of lack of computers in schools could be solved by schools themselves through working with the donor community and local businessmen to source much needed computer hardware and software.

\section{Conclusions}

Based on the findings of the study it was concluded that vast ICT opportunities that could be utilised by MU to implement its TP programmes exist. These opportunities range from using the web-camera to assess student teachers teaching in class, uploading documents online by both lecturers and student teachers, online sharing of information through the social media by lecturers and students as well as amongst students themselves, coaching and mentoring of student teachers online by lecturers and supervisors. It was also noted that there was an existence of threats that could inhibit MU form utilising ICT opportunities to implement its TP programmes if those threats were not dealt with.

\section{Recommendations}

Based on literature review and the findings of the study, the following recommendations were made:

Mthwakazi University (MU)

- $\mathrm{MU}$ as the main university should advise the Ministry of higher education to work with the Ministry of Information Communication and Technology to develop ICT infrastructure and connectivity in rural schools especially those that lack such infrastructure.

- MU should craft an ICT Policy and strategy with an implementation monitoring and evaluation plan.

- Mthwakazi University should come up with a budget to hire consultancy that will set up, manage and maintain ICT infrastructure that will support the implementation of TP programmes.

- Through adequate budgeting the university should use the intranet system to connect its-self with schools where their student teachers usually do teaching practice.

- The university should put in place adequate and up to date security system to safeguard both ICT hardware and software.

- Mthwakazi University should incorporate ICT into the curriculum of teacher training programmes in order to equip student teachers with knowledge and skills of using ICT, not only to communicate with their supervisors but to deliver lessons in class as well.

- MU should work with the donor community and 
other willing stakeholders to assist schools where they usually attach their student teachers to upgrade ICT infrastructure.

Department of teacher education

- Mthwakazi University department of teacher education should continuously upgrade and modernise its ICT infrastructure.

- Mthwakazi University Department of teacher education should organise workshops and seminars to train its lecturers on how to use ICT to deliver education and TP Programmes.

\section{Supervisors/lecturers}

- Supervisors should exploit ICT advancement opportunities to assess their students on line on issues for example such as quality of the lesson plan, lesson notes, power point presentation slides, evaluation and assessment as well as the quality of homework given to learners.

- MU lecturers should give student teachers on TP frequent and comprehensive feedback through ICT apparatus.

- For balance purposes it is recommended that MU lecturers should use a mix of ICT methods to implement their teaching practice programmes.

\section{Student teachers}

- Student teachers should be advocates of and promote the use of ICT in schools, either in delivering lessons or in communicating with local mentors, supervisors, students, colleagues and parents.

\section{REFERENCES}

[1] Cluckle P, Clarke S \& Jenkins I (2002) Students information and communications technology skills and their use during teacher training. Journal of information technology for teacher education 9 (1) pp2-22
[2] Harris D \& Anthony H (2001) Collegiality and its role in teacher development: Perspective from veteran and novice teachers. The development 5 (3) 371-389

[3] Oliver R (2010) The role of ICT in Higher Education for the 21st century, University, Perth, Western Australia

[4] Rodgers M (2008) Research Methodology and Techniques Great Britain Harcourt College Publishers

[5] Welman KM (2005) Research Methodology Cape Town Oxford University Press South Africa

[6] McMillan JH \& Schumacher (2010) Research in Education New Jersey Pearson Education

[7] Thomas M (2011) Digital Education: Opportunities for social collaboration Palgrave Macmillan

[8] Margaret L (2005) Towards a definition of the integration of ICT in the classroom, Parramatta New South Wales

[9] Kiggundu E \& Nayimuli S (2009) South African Journal of Education Vol 29 no.3 Pretoria

[10] Lave J \& Wenger E (1991) Situated Learning Cambridge University New York

[11] Hammond M (2001) A case exploring new information and communications technology teachers' satisfaction and development in their first year of teaching Teacher Development 5 (3) 339-356

[12] Interactive Educational Multimedia, Number 14 (April 2007), pp79-89

[13] Newhouse (2002) The impact of ICT on learning and teaching Perth, Western Australia

[14] Khalid AB (2009) Barriers to successful integration of ICT in teaching and learning environment RMIT University Australia

[15] Reddi UV (2010) Roles of ICT in Education and Development New Jersey USA

[16] Shelly GB, Gunter AG, Gunter RE (2010) Integrating Technology and Digital media in the classroom USA

[17] Pelgrum WJ (2001) Obstacles to the integration of ICT in education, computers and education $37,163-178$ 